\title{
ATTENDANCE INDICATORS FOR STUDENTS IN LONG-TERM NURSING COURSES AT A UNIVERSITY HOSPITAL
}

\author{
INDICADORES DE COMPARECIMENTO PARA ESTUDANTES EM CURSOS DE \\ LONGA DURAÇÃO EM ENFERMAGEM EM UM HOSPITAL UNIVERSITÁRIO
}

\section{Guilherme Silva MENDONÇA ${ }^{1}$; Cristiane Martins CUNHA ${ }^{2}$; Emenson Piantino DIAS ${ }^{3}$; Tatiana Carneiro de RESENDE ${ }^{4}$; Clesnan MENDES-RODRIGUES ${ }^{5}$}

1. Master Degree student in Postgraduate Program in Health Science, Federal University Uberlândia - UFU, Nurse and Pedagogue, Clinical Hospital of Uberlândia from Federal University Uberlândia, Uberlândia, MG, Brasil; 2. Doctoral student in Postgraduate Program in Fundamental Nursing from Nursing School of Ribeirão Preto, Nurse in Clinical Hospital of Uberlândia from UFU, Teacher of Nursing Course from UFU, Uberlândia, MG, Brasil; 3. Doctoral student in Postgraduate Program in Psychology from Pontifícia Católica de Minas Gerais University, Nurse and Teacher in Technical Health School from UFU, Uberlândia, MG, Brazil; 4. Master Degree in Health Science by Postgraduate Program in Health Science from UFU, Nurse and Teacher of Technical Health School from UFU, Uberlândia, MG, Brasil; 5. Doctor in Ecology by Postgraduate Program in Ecology and Natural Resources Conservation from UFU, Biologist, Nurse in Clinical Hospital of Uberlândia from UFU, Uberlândia, MG, Brazil; clesnan@ hotmail.com.

\begin{abstract}
Education is a social and universal phenomenon, being essential to the workplace and in a continuing regime. The pursuance of continuing education is common in the Nursing practice. Therefore, this study has the objective of describing the attendance indicators obtained by a Continuing Education Nursing Program at a University Hospital in 2012, in relation to the attendance of the students in long-term courses (greater than 20 hours). These courses are offered to the nursing staff under the pretext of understanding and supporting new health care strategies, which aim at improving the workforce of participants. The work herein is a descriptive, exploratory and retrospective study. During 2012 only three long-term courses were offered, all focused upon the specific needs of the hospital. In order to carry out the attendance evaluation a series of indicators were considered; daily presence percentage, general attendance percentage per student, attendance percentage of approved student, attendance percentage of reproved student, course abandonment percentage and approval percentage. The results showed differences in the attendance rates across all courses, both for those students who were approved as for those who were reproved, although the approval rate did not differ between the courses $(40-50 \%)$. In the case of the course offered only to nurses, there were no abandonments registered. A noted phenomenon is that over the period the course runs, there also occurs a decrease in the daily attendance percentage on the part of students, thus demonstrating the need to implement new methodologies concerning this problem. Additionally, there occurred an attendance percentage and an approved and reproved percentage differential in results among the three nursing work categories, where nurses presented the highest rates of attendance and approbation. These results can be associated to the workplace position, voluntary participation and absence of liberation criteria for participation, all of which should be investigated in a future scenario. The results demonstrate the need for a methodology that maintains attendance levels across the whole duration of the long-term course, and deals with the presence of different professional categories and functions in the same course, under the intention of improving attendance and results of the long-term courses in continuing education programs.
\end{abstract}

KEYWORDS: Continuing education. Nursing staff. Training courses.

\section{INTRODUCTION}

Education is a social and universal phenomenon, acting as a necessary human activity in the existence and proper workings of any society. Therefore, the formation of apt individuals becomes of primordial importance, seen through the aiding and development of a citizen in their physical and emotional capacities and preparing them for active and transformative participation during the various instances of social life (MORIN, 2002). Besides this, education is not merely a demand made through life in society, but also the process by which individuals are suffused with knowledge as well as cultural, moral and adaptive experience, thus making them apt to act within the social, global and planetary environments, or be it, are dependent upon the unity of knowledge.

When it comes to relating this concept of education into the nursing profession, also considered as a social practice, one understands that in every act in nursing there are educational aspects interlocked; directed as much towards the patient as to the professional. These acts should be directed towards the student during the learning process, to the professional during the working process and the population through the health-sickness process in order that they all become protagonists (ROVERE, 1993).

According to Lopes et al (2007), the PanAmerican Health Organization looked into the failures in the formation of health teams, in 
conjunction with the needs posed by the health service, and from the 1970`s suggested a debate directed to a new pedagogic model in order to improve health practices. Through an understanding that health planning and human resources planning are linked, a Latin-American study, which searched for alternatives in health training, was initiated. Within this scenario of alternatives, one can include Continuing Education. Here we treated Continuing Education as synonym of Permanent Education, since the first use of Continuing Education in English Scientific literature was in 1966 (see MeSH database descriptors) and Permanent Education is restricted to Brazilian literature.

During the Continuing Education process, many problems are resolved or equated in the work environment through onsite training. According to Bárcia (1982) due to the ambiguity surrounding the term of Continuing Education, there have been a number of variations such as permanent education, self-education, self-training, self-regulation, selfteaching, informal education, continued education, compensatory education, post-compulsory education and andragogy. When necessary, educational activities are constructed in an upward manner, taking into consideration the specific needs of the professional and teams. These educational activities are also constructed in a manner, which is articulated with the reorganizational processes of the system (attention, gesture, education, social control, written pleadings), all of which imply follow up and technical support. Examples of such being, building teams of specialists for providing technical support to primary care teams in specific themes of priority, the instituting of technical assessing processes for forming specific policies. It is understood that there may exist various obstacles and setbacks during their execution into health services (ROVERE, 1992; COTRIM-GUIMARÃES, 2009).

Based on these perspectives the continuing education sector of the Clinical Hospital of Uberlândia - Universidade Federal de Uberlândia (CHU-UFU) named CEPEPE (Centro de Pesquisa e Educação Permanente em Enfermagem or Center for Research and Continuing Education in Nursing), has as its mission: "to promote and research continuing education in nursing, from collective analysis of work processes. Thus, provide the tools for transforming practices along with the professional and human development of nursing teams from CHU-UFU, in order to adequately take on the roles of assistance, teaching, research, extension courses and management".

Onsite training is the best strategy in the development of nursing staff for improving care, as it opens the possibility for members to acquire or improve their knowledge or ability through learning. The teaching-learning process is lived through new educational tendencies that allow for the democratization of the education process, focused on the training and qualifying of citizens for the labour market. According to Ricaldoni and Sena (2006), "In the scope of education and health, the accumulation of knowledge, brought through technology and quality indicators of work processes, have influenced the work organization, demanding that workers acquire new abilities in a dynamic style". In compliance with Ordinance Number $198 / \mathrm{GM} / \mathrm{MS}$ of 2003 , in respect to the continuing health education policy, one notes that continuing education in health opens the possibility for the worker to add to their learning skill set, a critical reflection of their work environment, with the search for resolutions to clinical actions as well as promote the client's health (BRASIL, 2003). The educational level of professionals and the continuing education presence has been related to improvements of the quality indicators in health services (CHO et al. 2015).

According to Backes et al. (2003) continual education in nursing is defined "as an educational process, formal or informal, dynamic, dialogical and continual, with personal and professional revitalization and rewards". The proper working of the continuing education sector makes it possible for an organization to create new forms, with the aim of qualifying its employees. Continuing education has as its underlying feature the concept of significant learning, which involves a contextualized learning that includes a reflection and questioning, concerning situations lived out in the work environment, whereby the work and the worker are sources of knowledge. Besides those common features identified through this study, for each of the concepts clarified, one notes a great need for studies with more rigorous quantitative methodological approaches able to evaluate the effectiveness of continuing education programs in health institutions.

The study herein has as its objective to describe attendance indicators for courses in nursing offered by the Continuing Education Program for Nursing, promoted by CEPEPE of the Clinical Hospital of Uberlândia from the Federal University Uberlândia, in 2012. The attendance indicators studied herein are associated with long-term courses offered to the nursing staff, with the goal of offering the grounds for future methodologies for improving attendance of course participants. Besides evaluating the variation of attendance in function of the participant`s professional category and how their 
attendance evolves over the meetings or initial days of the course.

\section{MATERIAL AND METHODS}

\section{Type of study, Population and Sampling}

The study herein is a descriptive, exploratory and retrospective with a quantitative approach. The study was developed from information made available by the CEPEPE the Continuing Education Study Centre for Nursing from CHU- UFU. The hospital has 520 beds, and has a university and teaching characteristic, providing care in units of high and low complexity, outpatient clinics and emergency. In Nursing Department, the hospital is supported by around 1,150 employees/staff (189 nurses and 961 technicians and/or nursing aides, ANTUNES et al. 2013).

\section{Data Recruitment}

Data were collected concerning courses of long duration; here long-term course is defined as courses of 20 hours or more or with a schedule longer than one month. These courses were offered to the hospital's nursing staff and in some cases the Uberlândia municipal Nursing staff. The data obtained appertain to the period of January/2012 to December/2012. These data make up part of forms and administrative plans from CEPEPE and CHUUFU, where at the point of being made available for analysis, the names of the participants were excluded from administrative plans with only the participant's professional category being maintained. This information is open to the public and belongs to hospital management policy; consequently, the study was not submitted for review to the ethics committee. The decision to release such data for research or management use remains purely in the hands of the institution, and was approved internally. The courses included in the study were: Updates in Renal Replacement Therapies; Updates for Nursing Assistants in Mental Health of the Clinical Hospital of Uberlândia and the Management Training Course for Nurses. There was no information collected that allowed the identification of any participant to be known, whether they be organizers, professors or participants.

\section{Data Collection}

Descriptive information was collected concerning the courses, such as attendance and absences in classes of the referred courses. To outline the courses, evaluations were made as to periodicity, forms of participation, anticipated finish date, date course took place, length of course, duration in days, number of meetings, number of places, number of inscriptions, number of abandonments (subscribed participants who did not attend any class), criterion for approval (percentage of attendance total) and targeted audience.

\section{Attendance Indicators}

In order to evaluate attendance in the courses the following attendance indicators were assessed and utilized: the daily attendance percentage (number of participants present in each day of the course divided by the number of participants of the course); general attendance per student (number of attended course hours divided by the total number of administered course hours); attendance percentage per approved or reproved student (number of attended course hours divided by the total number of course hours administered, measured separately for approved or reproved student); absenteeism percentage (number of absent students divided by number of subscribed students) and approval percentage (number of approved students divided by number of subscribed students). All data were treated as percentages through the differences of course length, which allowed for a better comparison among the courses.

\section{The Effect of Professional Nursing Category}

The average attendance for each professional was compared among the three professional categories of Nursing staff (nurses, nurse aides (synonymous for nurse assistant or auxiliary), and nurse technician). The Professional category was based on the position for which each individual was hired. See details from each category and history in (BRAZIL, 1986; NEVES and MAURO, 2000). In this analysis, only those two courses where there existed participants from the three categories were included and compared (the Management Training Course where only nurses were present was excluded). However, for the approval, reproved and absenteeism/abandonment rates, these were compared using data from the three courses. The analyses were not carried out or compared for each course due to the low number of participants for each course.

\section{Statistical Analysis}

All data were analyzed with Generalized Linear Models. The percentages data were evaluated with logistical binominal distribution, where each class was attributed with attended (yes) or absent (no). When differences between the courses were 
detected, the values were compared, through the Least Significant Difference test (CRAWLEY, 2007). Every analysis was conducted using the GLzM SPSS 17.0 module, with tests of type III (SPSS, Inc., Chicago, IL, USA).

\section{RESULTS}

Through the collection of information related to courses offered, it was noted that during 2011, CEPEPE did not develop long-term courses, but provided classes of one hour per course (courses of short duration), with various sectors from the clinical hospital administering these courses. In 2012, CEPEPE continued to adopt the same methodology of training courses of one-hour duration and established courses in sectors with specific demands (long-term courses, with specific audiences and themes), offering only three courses: Updates in Renal Replacement Therapies; Updates for Nursing Assistants in Mental Health from CHU-
UFU and the Management Training Course for Nurses. The characteristic details for these courses can be seen in Table 1. The courses consisted of weekly classes, with voluntary participation and for all professional Nursing categories, with approval ratings varying between $59-75 \%$, with an exception being made in management training, intended solely for nurses. Even though all places for these courses were filled, absenteeism still occurred. The daily attendance percentages, per approved and reproved students as well as absent students varies among the three courses, with only the percentage for approved students remaining the same among all the courses (Table 2). As the courses run the percentage of daily attendance decreases in function of the order of classes, when evaluated separately for each course (Figure 1). This behavior also was observed when evaluated independent to the course and even when evaluated in function of the number of days that had run from the start of the course (results not showed).

Table 1. Feature profiles of long-term courses, 20 hours or more, offered by the Clinical Hospital of Uberlândia from Federal University of Uberlândia for Nursing staff in 2012.

\begin{tabular}{|c|c|c|c|}
\hline \multirow[b]{2}{*}{ Characteristics } & \multicolumn{3}{|c|}{ Course } \\
\hline & $\begin{array}{c}\text { Update in Renal } \\
\text { Replacement Therapies }\end{array}$ & $\begin{array}{c}\text { Update Nursing Care in } \\
\text { Mental Health }\end{array}$ & $\begin{array}{l}\text { Management Training } \\
\text { Course for Nurses }\end{array}$ \\
\hline Periodicity & one weekly meeting & two weekly meetings & one weekly meeting \\
\hline $\begin{array}{l}\text { Form of } \\
\text { participation }\end{array}$ & voluntary & voluntary & voluntary \\
\hline $\begin{array}{l}\text { Predicted course } \\
\text { period }\end{array}$ & $07 / 08 / 2012$ to $04 / 12 / 2012$ & $13 / 04 / 2012$ to $30 / 11 / 2012$ & $\begin{array}{l}12 / 04 / 2012 \text { to } \\
29 / 11 / 2012\end{array}$ \\
\hline Real course date & $14 / 08 / 2012$ to $05 / 12 / 2012$ & $13 / 04 / 2012$ to $30 / 11 / 2012$ & $\begin{array}{l}12 / 04 / 2012 \text { to } \\
22 / 11 / 2012\end{array}$ \\
\hline $\begin{array}{l}\text { Predicted running } \\
\text { time }\end{array}$ & 124 hours & 130 hours & 75 hours \\
\hline Real running time & 92 hours & 121 hours & 57 hours \\
\hline Duration in days & 113 & 231 & 224 \\
\hline $\mathrm{N}^{\circ}$ of meetings & 23 & 32 & 19 \\
\hline $\mathrm{N}^{\mathrm{o}}$ of places & 40 & 40 & 25 \\
\hline $\mathrm{N}^{\mathrm{o}}$ of subscribed & 35 & 41 & 25 \\
\hline $\mathrm{N}^{\circ}$ of drop outs & 5 & 5 & 0 \\
\hline $\mathrm{N}^{\mathrm{o}}$ of participants & 30 & 36 & 25 \\
\hline $\begin{array}{l}\text { Criterion for } \\
\text { approval (\% } \\
\text { attendance) }\end{array}$ & 69 hours $(75.00 \%)$ & 72 hours $(59.50 \%)$ & 42 hours $(73.68 \%)$ \\
\hline Target audience & $\begin{array}{c}\text { Professionals from the } \\
\text { Transplant Sector and } \\
\text { Haemodialysis and all } \\
\text { other interested nursing } \\
\text { staff }\end{array}$ & $\begin{array}{l}\text { Professionals that work in } \\
\text { Mental Health in the } \\
\text { Hospital and the Municipal } \\
\text { Council of Uberlândia }\end{array}$ & $\begin{array}{c}\text { Nurses that work in } \\
\text { Managerial Positions } \\
\text { and all other interested } \\
\text { nurses staff }\end{array}$ \\
\hline
\end{tabular}


Table 2. Attendance indicators for long-term courses, 20 hours or more, offered by Clinical Hospital of Uberlândia from Federal University of Uberlândia in 2012 for Nursing staff.

\begin{tabular}{|c|c|c|c|c|c|}
\hline \multirow[b]{2}{*}{ Indicators } & & \multicolumn{3}{|c|}{ Course $^{1}$} & \multirow[b]{2}{*}{$\begin{array}{c}\text { Wald Chi- } \\
\text { square, } d . f .=2 \\
(P)\end{array}$} \\
\hline & & $\begin{array}{c}\text { Renal } \\
\text { Replacement } \\
\text { Therapies } \\
\text { Update } \\
\end{array}$ & $\begin{array}{l}\text { Nursing Care in } \\
\text { Mental Health } \\
\text { Update }\end{array}$ & $\begin{array}{l}\text { Management } \\
\text { Training } \\
\text { Course for } \\
\text { Nurses } \\
\end{array}$ & \\
\hline \multirow[t]{2}{*}{$\begin{array}{l}\text { Daily } \\
\text { attendance } \\
\text { percentage }(\%)\end{array}$} & $\begin{array}{l}\text { Average } \\
\pm \mathrm{SE}\end{array}$ & $59.42 \pm 3.30 \mathrm{a}$ & $53.21 \pm 1.70 \mathrm{~b}$ & $64.00 \pm 3.37 \mathrm{a}$ & $17.77(<0.001)$ \\
\hline & Range & $23.33-90.00$ & $36.11-75.00$ & $24.00-92.00$ & \\
\hline \multirow{2}{*}{$\begin{array}{l}\text { General } \\
\text { attendance } \\
\text { percentage per } \\
\text { student }(\%)\end{array}$} & $\begin{array}{l}\text { Average } \\
\pm \mathrm{SE}\end{array}$ & $59.42 \pm 5.27 \mathrm{~b}$ & $53.44 \pm 5.34 \mathrm{c}$ & $64.00 \pm 4.27 \mathrm{a}$ & $57.29(<0.001)$ \\
\hline & Range & $8.70-100.00$ & $2.48-100.00$ & $10.53-94.74$ & \\
\hline \multirow{2}{*}{$\begin{array}{l}\text { Attendance } \\
\text { percentage of } \\
\text { approved } \\
\text { student }(\%)\end{array}$} & $\begin{array}{l}\text { Average } \\
\pm \mathrm{SE}\end{array}$ & $87.32 \pm 1.36 \mathrm{a}$ & $79.77 \pm 2.48 \mathrm{~b}$ & $84.21 \pm 2.60 \mathrm{a}$ & $30.31(<0.001)$ \\
\hline & Range & $82.61-100.00$ & $62.81-100.00$ & $73.68-94.74$ & \\
\hline \multirow{2}{*}{$\begin{array}{l}\text { Attendance } \\
\text { percentage of } \\
\text { reproved } \\
\text { student }(\%)\end{array}$} & $\begin{array}{l}\text { Average } \\
\pm \text { SE }\end{array}$ & $40.82 \pm 5.22 b$ & $24.02 \pm 4.65 \mathrm{c}$ & $50.53 \pm 3.00 \mathrm{a}$ & $217.16(<0.001)$ \\
\hline & Range & $8.70-73.91$ & $2.48-58.68$ & 10.5368 .42 & \\
\hline $\begin{array}{l}\text { Absenteeism } \\
\text { percentage }(\%)\end{array}$ & & $14.29 \mathrm{a}$ & $12.20 \mathrm{a}$ & $0.00 \mathrm{~b}$ & $6.11(0.047)$ \\
\hline $\begin{array}{l}\text { Approval } \\
\text { percentage }(\%)\end{array}$ & & $40.00 \mathrm{a}$ & $52.78 \mathrm{a}$ & $40.00 \mathrm{a}$ & $1.42(0.490)$ \\
\hline
\end{tabular}

Legend: SE - standard error, $d . f$. - degrees of freedom, $P=$ probability; ${ }^{1}$ Values followed by the same letter on the line are different based on the test of Least Significant Difference $(P<0.05)$.

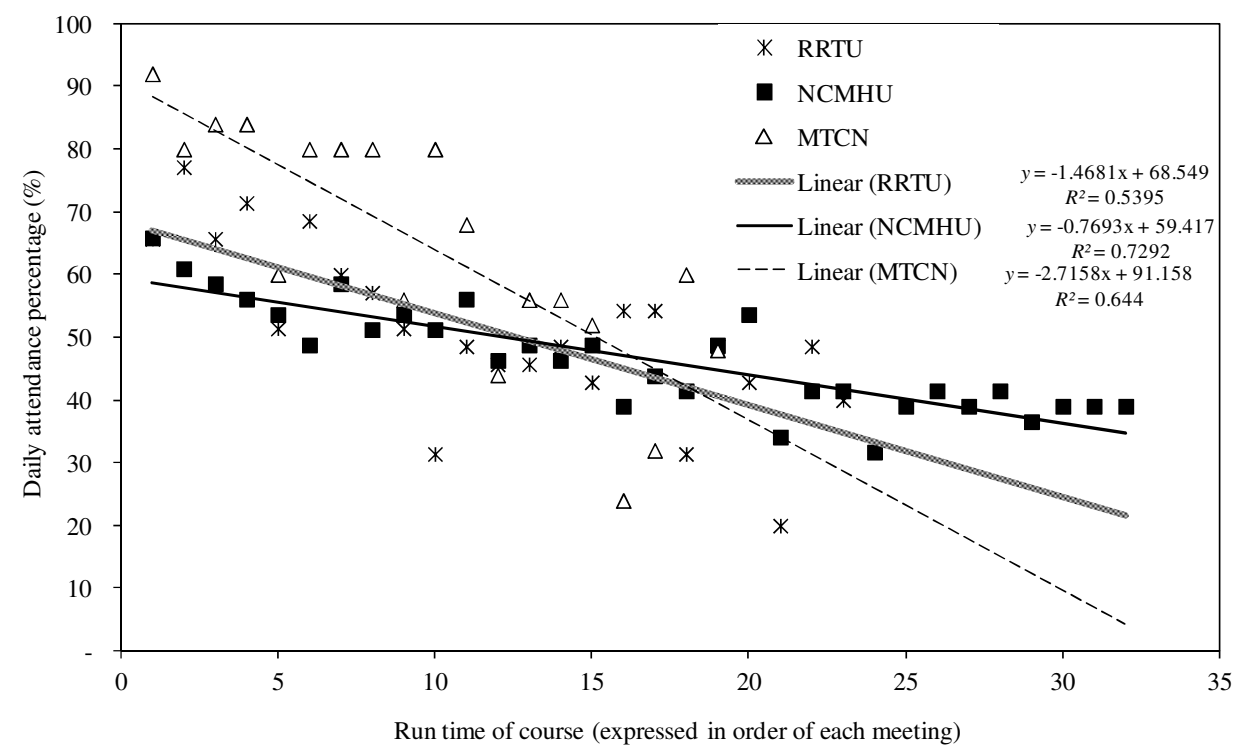

Figure 1. Relationship between the daily attendance percentage and the run time of the long-term course offered during 2012 at the Clinical Hospital of Uberlândia for Nursing staff. Legend: RRTU (Renal Replacement Therapies Update), NCMHU (Nursing Care in Mental Health Update) and MTCN (Management Training Course for Nurses). 
Attendance percentage varied among the three professional categories, with nurses showing the highest percentage of attendance for the courses (Figure 2). This also reflected in the rates of approved, reproved and absenteeism/abandonment students in those courses, which differed among the three professional categories (Figure 3). Nurses showed a greater approval rate and lower reproved and absenteeism rates than the other categories.

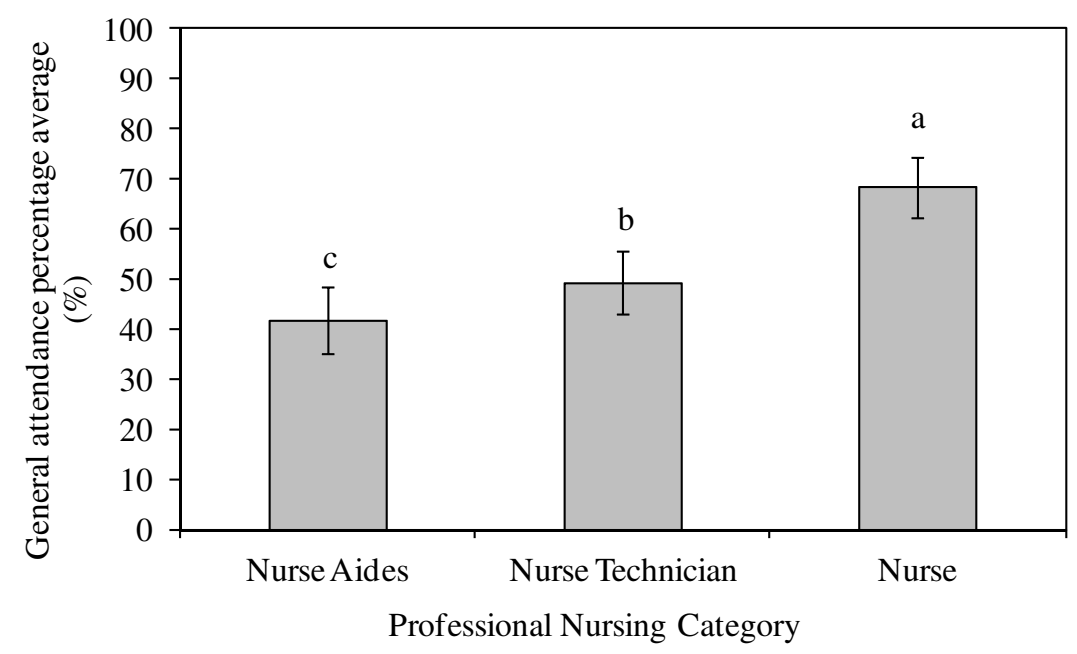

Figure 2. General attendance percentage average in function of professional nursing category over two longterm courses offered in 2012 at the Clinical Hospital of Uberlândia. Averages ( \pm standard error) followed by distinct letters are different based on the test of Least Significant Difference (Chi-squared of Wald: $340.55 ; P<0.001, d . f .=2$ ).

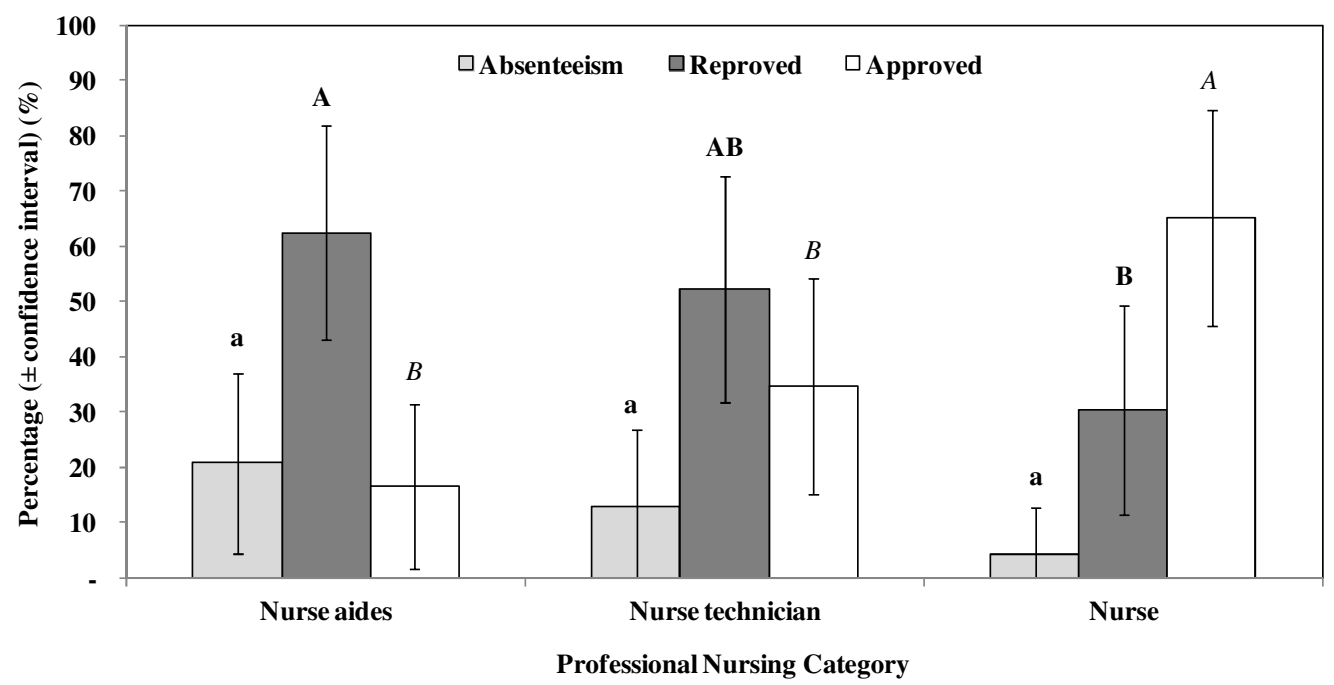

Figure 3. Percentage ( \pm confidence interval) of absenteeism, reproved and approved students in function of the professional Nursing category in two long-term courses offered in 2012 at the Clinical Hospital of Uberlândia. Percentages followed by distinct letters for each criterion are different based on the test of Least Significant Difference; with lower case letters for absenteeism (Chi-squared of Wald: 2.46; d.f. $=2 ; P=0.293$ ), upper case letters for reproved (Chi-squared of Wald: $8.41 ; d . f .=2 ; P=0.090)$ and upper case letters and in italics for approved (Chi-squared of Wald: 10.67; d.f. $=2 ; P<0.005$ ). 


\section{DISCUSSION}

In December/2010, CEPEPE, faced with the need to implement a continuing education system from the CHU-UFU nursing team elaborated a training nucleus for the 1 st semester of 2012. The Nursing Team Continuing Education Program from CHU-UFU - Module I, in January/2012 installed this nucleus as a goal to reach an improvement in the quality of care from the CHU-UFU nursing team and that these procedures would be standardized within the hospital regime. Besides this, the nucleus was composed of short-term courses (maximum 1 hour duration per course) and long-term courses; like those evaluated herein, they attend to the specific needs of units or some area of operation. The management of these courses had seen the need for an evaluation of results (personal communication) for a change in strategy faced with the high rate of absenteeism and reproved students in these courses. The main problem was understood to originate in the low level of attendance. When developing a training course it is essential to assure its effectiveness, which makes the item of evaluation of the developed training course one of great importance. In order to apply the evaluation of a training program, one can use various instruments for the task of evaluation, which allow one to measure the efficiency, effectiveness, attendance, applicability, interest and satisfaction of the client/participant, among the various other items that can be judged as necessary for the effectiveness of the course. Among the various available methodologies and instruments for use in evaluation encountered in the literature, the authors highlight Bourdieu (1990), Carvalho and Nascimento (1999) and Kirkpatrik (1998). In all studies, the importance of the evaluation of the results for the continuing education programs is evident, as demonstrated in some theoretical reviews (e.g. GRISCTI; JACONO, 2006).

However, in this context, qualitative approach studies with content analyses are somewhat more common (e.g. MICAS and BATISTA, 2014); but the use of this methodology for the comparison of different courses in retrospective studies could present difficulties. A mixed quantitative-qualitative case study clearly contains a symbolic dimension, in which event means they refer to social-cognitive schemes and the qualitative case study, the most commonly adopted is that which is based on applying questions, where the surveyed individual is asked to choose an alternative presented under the form of evaluative adjectives such as: excellent, good, regular, bad etc. This is clearly inadequate when seen from the point of view of providing information on proponents of the course (BOURDIEU, 1990).

The act of evaluation in continuing education should compose of methods and procedures that allow the institution to identify and measure the results reached by the applied program. Through the application of this evaluation mechanism, the institution is able to compare the results obtained by the instrument with the proposed objectives, thus making it possible to refeed into the program compensatory information for the elaboration of new programs or the improvement of those already in existence. The evaluation of educative actions can be characterized by being any attempt that tries to obtain information (refeed), on the effects of a training program and determining its value through the use of such information (CARVALHO; NASCIMENTO, 1999).

According to Kirkpatrick (1998), in developing an evaluative study of a training program, the company should have the objective of implementing the program, where the company obtains concrete information for making decisions in relation to its programs and investments. In this context, the attendance indicators used here by the authors were informative and allow for discussion, which can produce future corrective actions, if they are evaluated during the running of the courses.

Based on the evaluative instruments found in the literature and the methodology applied to the long-term courses; one notes from the obtained results that during the running of the course, absenteeism was very well pronounced. This led to various individuals to drop out/abandon as well as produce a low level of attendance and approval rates of participants for the long-term courses offered by the sector. Data of this type aids in providing the institution with information, in order that it may adopt new methodologies and structure courses with a view to higher attendance in training programs. Similar studies are absent, but factors related to no participation in continuing education are related to deficits in nursing staff, health work activities, cost of courses, no release to participation and participation outside of working hours (e.g. BREWER, et al., 2006; NI, et al., 2014).

Due to the fact that the attendance indicator evaluations were a posteriori, it was not possible to intervene with the courses referred to herein. The main problem involved in attendance of these courses is found in the fact that the course is held outside of working hours, in a voluntary manner. Such processes make performance and student 
involvement difficult, opening the question as to whether all courses should be offered during the work period, thus permitting the institution to adequately manipulate the curriculum to its needs and not to the staffs. When courses are offered on a voluntary basis, staff choose and sign up to those courses that attend more to their needs than those of the hospital, thus forcing the Continuing Education program in a direction that does not attend to the institution's necessities. The conflict between the institution's demands and those of the staff has been raised as a factor that can make Continuing Education difficult (ROVERE, 1993). As it stands, the mandatory participation in continuing education is growing as a lawful requirement from nursing policies both in classes association and national legislation (ROSS, et al., 2013). The mandatory versus voluntary participations also is in ample discussion in literature related to continuing education (GRISCTI; JACONO, 2006).

Another factor that weighs upon low attendance is the scale of staff inadequacies. To understand this in a comparative manner, in 20132014, the CHU-UFU, presented a deficit of around 492 Nursing Professionals, according to scale demanded in 2013 (ANTUNES et al. 2013). Unfortunately, the authors do not have at hand data for deficits concerning 2012. With this being the case, staff who subscribe into a course end up having to relocate to a care work shift, which is detriment to the training course; even though the course offered is of a voluntary nature. However, to find an adequate solution to this problem public policies are necessary, which are out of the control of any hospital. Although, Cotrim-Magalhães (2009) showed that staff report that nonparticipation in educational activities can on many occasions be related to lack of management and work organization than work overload.

However, the differential in achievement among the different professional categories is worrying, since it may only be an exaggeration of these criteria. Nurses may therefore be more avid or have greater availability for voluntary courses and the demand made on staff less critical for this category. Although the authors believe that the last criterion is not true, since what we do believe is that Nurses are more involved in work management and this means that they can be directed in an easier fashion in terms of course participation, on many occasions the thought is this can act as a multiplication factor. On many occasions, the participants are freed up in order to participate in the course. This fact is proven by the higher attendance rate in the management courses. The authors do not believe that low attendance for assistants and technicians is related to technical training, since a large number of this staff is studying or has already studied in higher education, besides their participation has already been calculated into the improved carrier plan for both categories (BRASIL, 2005). The differential results among nursing professionals category is commonly present in literature (e. g. CASTELHÕES; SILVA, 2007; GRANZOTTO, et. al., 2008), reinforcing the need to consider new methodologies that take this fact into account.

Another factor that may be associated with this phenomenon is employment category, which here is defined as the function that the employee executes in the institution. The fact for example to be in care or administration may be linked more to the results found by the authors. The authors believe that the higher participation of nurses may be related to their greater link to administrative positions and therefore, greater possibility of being giving leave to participate, while those associated with direct patient care end up participating exclusively on a voluntary criterion. Although the authors cannot conclude anything concerning these courses, once it was shown that such a situation did not arise, partly due to the impossibility associated with the identification of study participants.

Probably, only the decrease of working hours or the period of the course is not sufficient criteria for improving attendance. The minimum shift of 20 hours is part of what is demanded from the Carrier Plan for Federal Employees (BRASIL, 2005), with many activities and sector needs demanding a heavy working schedule to be followed. However, decreasing the period of the course may be an alternative, but this may aggravate problems with freeing up a high number of workers at the same time over a short time period. Therefore, the adoption of themes directed towards the needs of the unit or the passing on of technology, is in itself a reason for a low adherence of employees (COTRIM-MAGALHÃES, 2009). Training indicators in Brazilian literature have shown that a healthcare professional receives below 20 hours per year of training (e.g. OLIVEIRA, et al., 2014), demonstrating the low adherence to Continuing Education Programs.

Therefore it becomes apparent the need to adopt some strategies for improving these results, as for example running the course during work hours, freeing up individuals in accordance with shift, obligatory participation, events with a shorter intervals or condensed, didactics and content directed towards both professional categories. Equal 
participation and the freeing up of both the care or management categories. As in our case it was not possible to evaluate what led to these results, future studies should evaluate the effect of voluntary participation against obligatory. The effect of position in the institution (boss, administration or social), the social-demographic profile of the participants (double-shift, age, carrier plan position, etc.), and an evaluation a posteriori of the factors that lead to a participant not to complete the course or an individual class. Preliminary results concerning the execution of the program the continuing education program of 2013-2014 in the same institution, where the courses are administered during the working shift and under obligatory participation, has shown positive results, although the indicators are still incomplete and have not been submitted to rigorous evaluation (C. MendesRodrigues, personal communication).

With the results presented herein at hand, one can inquire into the need for new methodologies in order to develop long-term training courses, given that the training focus at the end of the course is not the same as what it was at the start. Another instigating fact consists of offering the same training to different categories of professional or employee classes, which may generate conflict and indifference from some when approached on certain topics concerning the other category or class, independent of being professional or staff. Based on the collected results, the authors propose that a short-duration course methodology be adopted, focused upon the training needs of the professional team and aimed at staff and specific professional categories, running during work hours and not on a volunteer basis.

\section{ACKNOWLEDGEMENTS}

The authors would like to thank the members of the Center for Research and Continuing Education in Nursing (CEPEPE) and the Board of Nursing of Clinical Hospital of Uberlândia, for the implementation of courses and release of data for this study, with special thanks to Maria Auxiliadora Silva Costa and Angela Maria Machado. To the Vernon Sipple for the English version. Along with the anonymous reviewers and their suggestions.

RESUMO: A educação é um fenômeno social e universal, sendo essencial para o local de trabalho e em regime contínuo. A educação continuada é uma prática comum da enfermagem. Portanto, este estudo tem o objetivo de descrever os indicadores de comparecimento obtidos por um programa de educação continuada de enfermagem em um Hospital Universitário em 2012, em relação à participação dos alunos em cursos de longa duração (superior a 20 horas). Estes cursos são oferecidos para a equipe de enfermagem sob o pretexto de compreensão e apoio a novas estratégias de cuidados de saúde, que visam à melhoria da força de trabalho dos participantes. O trabalho é um estudo descritivo, exploratório e retrospectivo. Durante 2012 foram oferecidos apenas três cursos de longo prazo, todos focados nas necessidades específicas do hospital. A fim de realizar a avaliação do comparecimento uma série de indicadores foi considerada, sendo o percentual de comparecimento diário, percentual de comparecimento geral por aluno, percentual de comparecimento por estudante aprovado, porcentual de comparecimento por alunos reprovado, percentual de abandono e de aprovação por curso. Os resultados mostraram diferenças nos percentuais de comparecimento em todos os cursos, tanto para aqueles alunos que foram aprovados quanto àqueles que foram reprovados, embora o percentual de aprovação não diferiu entre os cursos (40-50\%). No caso do curso oferecido apenas aos enfermeiros, não houve nenhuma abandono registrado. Um fenômeno notável é que durante o período que o curso foi executado, também ocorreu uma diminuição do percentual de comparecimento geral por parte dos alunos, demonstrando assim a necessidade de se implementar novas metodologias relativas a este problema. Além disso; o percentual de comparecimento, os percentuais de alunos aprovados e de reprovados foram diferentes entre as três categorias de trabalho da enfermagem, onde enfermeiros apresentaram os maiores percentuais de comparecimento e de aprovação. Estes resultados podem ser associados à posição gerencial no local de trabalho, a participação voluntária e a ausência de critérios de liberação para participação nos cursos, associações que devem ser investigadas em um cenário futuro. Os resultados demonstram a necessidade de uma metodologia que mantenha os percentuais de comparecimento ao longo de toda a duração do curso e que lide com a presença de diferentes categorias profissionais e funções no mesmo curso, sob a intenção de melhorar o comparecimento e os resultados dos cursos de longo prazo nos programas de educação continuada.

PALAVRAS-CHAVE: Educação continuada. Equipe de enfermagem. Cursos de capacitação. 


\section{REFERENCES}

ANTUNES, A. V; RODRIGUES, C. M.; GOMES, F. A.; JÚNIOR REZENDE, G.; BRAGA, I. A.; TEIXEIRA, L. M. R. F.; MONTEIRO, A. B. C. Dimensionamento de Pessoal de Enfermagem. Uberlândia: Universidade Federal de Uberlândia - Hospital de Clínicas de Uberlândia, 2013. 93 p. (Relatório Técnico)

BACKES, V. M. S.; SCHMIDT, S. M. S.; NIETSCHE, E. A.; SAURIN, M. H. G.; FERRAZ, F. Educação continuada: algumas considerações na história da educação e os reflexos na Enfermagem. Texto \& Contexto Enfermagem, Florianópolis: Santa Catarina, v. 12, n. 1, p. 80-88, jan-mar. 2003.

BÁRCIA, M. F. Educação Permanente no Brasil. Petrópolis: Vozes, 1982

BOURDIEU, P. Structures, habitus, practices. Cambridge: Polity, USA, p. 52-65, 1990.

BRASIL. Ministério da Saúde. Dispõe sobre a Regulamentação do Exercício da Enfermagem e dá outras providências. Lei 7.498, de Brasília, 25 June 1986.

BREWER, C. S.; ZAYAS, L.E., SIENKIEWICZ, M. J.. Nursing recruitment and retention in New York State: a qualitative workforce needs assessment. Policy, Politics, \& Nursing Practice, Thousand Oaks: California, v. 7, n. 1, p. 54-63, feb. 2006.

BRASIL. Ministério da Saúde. Institui a Política Nacional de Educação Permanente em Saúde como Estratégia do Sistema Único de Saúde para a formação e o desenvolvimento de trabalhadores para o setor e dá outras providências. Portaria n. 198, Brasília, 13 feb. 2003.

BRASIL. Presidência da República, Casa Civil, Subchefia para Assuntos Jurídicos, Lei n ${ }^{\circ}$ 11.091, Brasília, 12 jan. 2005.

CARVAlHO, A. V.; NASCIMENTO, L. P. Administração de Recursos Humanos. São Paulo: Pioneira, São Paulo: Atlas, v. 1, 2 ed., 1999.

CASTELLÕES, T. M. F. W.; SILVA, L. D. Resultados da capacitação para a prevenção da extubação acidental associada aos cuidados de Enfermagem. Revista Mineira de Enfermagem, Belo Horizonte: Minas Gerais, v. 11, n. 2, p. 168-175, apr-jun. 2007.

CHO, E.; SLOANE, D. M.; KIM, E. Y.; KIM, S.; CHOI, M.; YOO, I. Y.; LEE, H. S.; AIKEN, L. H. Effects of nurse staffing, work environments, and education on patient mortality: An observational study. International Journal of Nursing Studies, Oxford: England, v. 52, n. 2, p. 535-542, feb. 2015.

http://dx.doi.org/10.1016/j.ijnurstu.2014.08.006

COTRIM-GUimarÃES, I. M. A. Programa de educação permanente e continuada da equipe de enfermagem da clínica médica do Hospital Universitário Clemente de Faria: análise e proposições. 2009. 132 f. Dissertação (Mestrado profissionalizante em Gestão do Trabalho e da Educação na Saúde). Escola Nacional de Saúde Pública Sergio Arouca, Rio de Janeiro, 2009.

CRAWLEY, M. J. The R Book. Chichester, USA: John Wiley and Sons, Ltd., 2007. http://dx.doi.org/10.1002/9780470515075

GRANZOTTO, J. A.; SCHNEID, S.; VECCHI, A.; et al. Basic life support training in a university hospital. Revista da AMRIGS, Porto Alegre: Rio Grande do Sul, v. 52, n. 1, p. 24-28, jan-mar. 2008.

GRISCTI, O.; JACONO, J. Effectiveness of continuing education programmes in nursing: literature review. Journal of Advance Nursing, London, v. 55, n. 4, p. 449-456, aug. 2006. http://dx.doi.org/10.1111/j.13652648.2006.03940.x 
KIRKPATRICK, Donald L. Evaluating Training Programs. São Francisco: Berrett - Koehler Publishers, Inc., 2 ed., 1998.

LOPES, S. R. S.; PIOVESAN, E. T. A.; MELO, L. O.; PEREIRA, M. F.. Potencialidades da educação permanente para a transformação das práticas de saúde. Comunicação em ciências da saúde, Brasília, v. 18, n. 2, p. 147-155, feb. 2007.

MICCAS, F. L.; BATISTA, S. H. S. S. Permanent education in health: a review. Revista de Saúde Pública, São Paulo, v. 48, n. 1, p. 170-185, feb. 2014. http://dx.doi.org/10.1590/S0034-8910.2014048004498

MORIN, E. Os sete saberes necessários á educação do futuro. Brasília: Cortez-Unesco, 5. ed., 118 p., 2002.

NEVES, E.; MAURO, M. Nursing in Brazil: trajectory, conquests and challenges. Online Journal of Issues in Nursing, Silver Spring: Maryland, v. 6, n. 1, dec. 2000.

NI, C.; HUA, Y.; SHAO, P.; WALLEN, G. R.; XU, S.; LI, L. Continuing education among Chinese nurses: A general hospital-based study, Nurse Education Today, Edinburgh: Scotland, v. 34, n. 4, p. 592-597, apr. 2014.

OLIVEIRA, J. L. C.; NICOLA, A. L.; SOUZA, A, E, B, R. Índice de treinamento de enfermagem enquanto indicador de qualidade de gestão de recursos humanos. Revista de Enfermagem da Universidade Federal de Santa Maria, Santa Maria: Rio Grande do Sul, v. 4, n. 1, p. 181-188, jan-mar. 2014.

RICALDONI, C. A. C.; SENA, R. R. Educação Permanente: uma ferramenta para pensar e agir no trabalho de enfermagem. Revista Latino-Americana de Enfermagem, Ribeirão Preto: São Paulo, v. 14, n. 6, p. 837-842, nov-dec. 2006.

ROSS, K.; BARR, J.; STEVENS, J. Mandatory continuing professional development requirements: what does this mean for Australian nurses. BMC Nursing, London, v. 12, n. 9, mar. 2013.

ROVERE, M. R. Gestion de La Educacion Permanente: una relectura desde una perspectiva estratégica. Educación médica y salud, Washington, v. 27, n. 4, p. 489-515, oct-dec. 1993.

ROVERE, M. International dimension of health. In: FERREIRA, J. R. et al. (eds). International Health: A North-South Debate, Washington, USA, Pan American Health Organization / World Health Organization (PAHO/WHO), USA, n. 95, p. 149-164, 1992. 